\title{
ДОСВІД ОРГАНІЗАЦІЇ НАВЧАЛЬНОГО ПРОЦЕСУ У ВИЩИХ МЕДИЧНИХ НАВЧАЛЬНИХ ЗАКЛАДАХ ПОЛЬЩІ
}

\author{
А. Е. Дорофєєв, Т. В. Мягкова, Джоанна Хоростовська-Винімко \\ Донеиький наиіональний медичний університет ім. М. Горького, \\ Польський начіональний інститут хвороб легень і туберкульозу, Вариава

\section{THE EXPERIENCE OF THE ORGANIZATION OF EDUCATIONAL PROCESS IN THE HIGHER MEDICAL EDUCATIONAL INSTITUTIONS OF POLAND}

\author{
A. E. Dorofieyev, T. V. Myahkova, Joanna Khorostovska-Wynimko \\ Donetsk National Medical University by M. Horkyi, \\ Polish National Tuberculosis and Lung Diseases Research Institute, Warsaw
}

\begin{abstract}
У статті акцентується увага на особливостях організації навчального процесу у вищих медичних навчальних закладах Польщі, дається аналіз порядку одержання диплома лікаря та перспективи наукової співпраці між університетськими клініками України та Польщі.

In the article the attention is focused on the features of the organization of educational process in the higher medical educational institutions of Poland, the analysis of an order of reception of the diploma of the doctor and prospects of continuation of cooperation between university clinics of Ukraine and Poland is given.
\end{abstract}

Вступ. У 2008 р. Польський національний інститут захворювань легень і туберкульозу та Донецький національний медичний університет, відповідно до програми Міністерства іноземних справ Польщі "Polska pomoc zagranica", уклали договір про співробітництво. У рамках цього проекту 8 наукових співробітників кафедри внутрішньої медицини № 2 ДонНМУ пройшли наукове стажування в декількох польських університетських клініках. Цільовий візит професора кафедри, візити з обміну досвідом доцента й молодих вчених дозволили ознайомитися з системою медичної допомоги та освіти в Польщі, сучасними науковими напрямами досліджень у пульмонології. У свою чергу, науковий співробітник польського інституту у рамках спільного наукового дослідження $\alpha 1$-антитрипсину відвідав із візитом кафедру внутрішньої медицини № 2 ДонНМУ.

У жовтні-листопаді 2009 року ми ознайомилися 3 роботою клініки й кафедри хвороб легень і туберкульозу (м. Забже) Сілезького медичного університету в м. Катовіце. У статті проаналізовано інформацію, зібрану в процесі стажування.

Основна частина. Медичний університет Сілезії, один 3 найбільших медичних навчальних центрів Польщі та центральної Європи, був заснований
1948 р. у м. Битом-Рокітіца. Статус університету медична академія одержала $1990 \mathrm{p}$.

У травні 2004 року Польща приєдналася до Свропейського Союзу. Освіта в Польщі відповідає Міжнародним нормам класифікації освіти (ISCED). Дипломи польських ВНЗ автоматично визнаються в усіх країнах Європи, при цьому додаткового підтвердження не потрібно. Згідно з національним законодавством розвинених країн, випускники, що одержали дипломи будь-якого медичного ВНЗ, зареєстрованого ВООЗ, мають однакові права. Пройшовши однотипні тести, які визначають рівень індивідуальних знань, спеціалісти можуть претендувати на лікарську практику в будь-якій країні, незалежно від того, в якому ВНЗ вони одержали медичну освіту.

Польща бере активну участь у Болонському процесі. Завдяки ЕCTS (European Credit Transfer System), за бажання, студенти польських ВНЗ можуть без проблем продовжити свою освіту в будь-якому навчальному закладі Європи. Випускники ВНЗ Польщі, які володіють англійською, польською та іншими іноземними мовами, успішно конкурують на міжнародних ринках праці не тільки в Польщі, а й у різних міжнародних компаніях за їі межами. Також вони мають чудову можливість залишитися після його закінчен-

(ㄱ А. Е. Дорофєєв, Т. В. Мягкова, Джоанна Хоростовська-Винімко 
ня працювати в Польщі, а за бажанням переїхати в інші країни Свропейського Союзу.

Студенти, що пройшли за конкурсом на вступних екзаменах, навчаються на денному відділенні безплатно й фінансуються 3 державного бюджету. Навчання іноземних студентів у більшості випадків платне, за винятком декількох нечисленних категорій.

Керівником медичного ВНЗ є ректор, факультетів (відділів) - декани. Представником студентів є орган студентського самоврядування університету - “студентський уряд”. За погодженням із “студентським урядом" декан призначає опікуна навчального року. До обов'язків опікунів серед іншого входять: 1) ознайомлення з умовами навчання інвалідів і спеціальним доглядом за ними; 2) захист прав студентів; 3) робота в тісному контакті з органами студентського самоврядування з усіх питань, пов'язаних 3 процесом навчання та соціально-побутовими умовами, а також скликання нарад педагогів за необхідності. Декан на прохання студентів або з інших поважних причин може звільнити наставника року.

У деяких категорій студентів білышості медичних ВН3 Польщі є право на індивідуальну організацію навчання. Це такі категорії студентів: 1) члени національних спортивних команд; 2) батьки-одинаки, що виховують дітей; 3) інваліди; 4) інші- на основі рішення декана.

Згоду на індивідуальну організацію навчання видає декан. Індивідуальна організація навчання не повинна впливати на тривалість часу навчального плану, визначеного програмою.

Академічний рік у ВНЗ починається 1 жовтня й триває до 30 вересня наступного календарного року. Академічний рік включає 2 семестри - зимовий і літній. Навчальний рік складається з тридцяти тижнів (приблизно по тридцять годин занять кожен) і поділений на два семестри. Зимовий семестр, що триває 31 жовтня до 15 лютого наступного календарного року, складається з 15 тижнів занять, зимової екзаменаційної сесії та канікул. Літній семестр, що триває приблизно з 16 лютого до 30 вересня, складається 315 тижнів занять і літньої екзаменаційної сесії. Один місяць під час літніх канікул, як правило, відводиться на професійну практику.

Навчальний графік встановлює вищий навчальний заклад. Викладання ведеться у формі лекцій, практичних і лабораторних занять, семінарів і співбесід. Такий розклад кожного академічного року, який публікується до 15 вересня, визначає ректор. Навчання на медичному факультеті триває 6 років.

Права та обов' язки студента, пов'язані з навчальним процесом, регулюються уставом конкретного ВНЗ.
Заліковим періодом є семестр або навчальний рік. Студенти складають екзамени 3 кожного предмета окремо. Щоб завершити семестр або рік, студент зобов' язаний скласти заліки й екзамени з усіх предметів, що є в навчальному розкладі, й одержати 3 них оцінки не нижче, ніж “задовільно”. Студент також зобов' язаний пройти практику, передбачену навчальним планом, і одержати залік.

Практичні заняття студентів старших курсів медичного університету Сілезії проходять у відомих і поважних не тільки в Польщі, а й у країнах Свропи клініках: Сілезькому центрі хвороб серця (м. Забже), Верхньосілезькому медичному центрі, Онкологічному центрі - Інституті ім. Марії Склодовської-Кюрі (м. Глівіце), Центрі лікування опіків (м. Семяновіце Шльонські), Клініці хвороб легень і туберкульозу (м. Забже).

Кожен ВНЗ встановлює свою шкалу оцінок, закріплену в уставі. Найбілыш розповсюдженою $є$ така схема: - відмінно (5), - дуже добре (4+ або 4,5), добре (4), - досить задовільно (3+ або 3,5), - задовільно (3), - незадовільно (2). Крім вищенаведеної шкали оцінок, польські ВНЗ поступово вводять Свропейську систему трансферу кредитних пунктів (ECTS). Щоб успішно закінчити семестр або навчальний рік, необхідно набрати відповідно від 30 до 60 пунктів.

Для одержання диплома про закінчення вищого навчального закладу необхідно одержати заліки з усіх предметів, практичних і лабораторних занять, передбачених навчальним планом, і скласти всі екзамени, встановлені для кожного напрямку навчання. Після завершення навчання в диплом вноситься остаточний результат оцінки, одержаний через підрахунок середньої арифметичної величини оцінок, згідно 3 принципом: до 3,24 - достатньо, 3,25-3,75 - досить добре, 3,76-4,10 - добре, 4,11-4,50 - більш ніж добpe, 4,51 i білыше - дуже добре.

Польські ВН3, зокрема медичні, беруть участь у міжнародних стипендіальних програмах, таких як “Сократ - Еразм”, які передбачають часткове навчання поза рідним ВН3. Socrates/Erasmus передбачає співробітництво з європейськими університетами і навіть прийом європейських студентів на короткострокове навчання. Польський національний інститут захворювань легень і туберкульозу має тісні взаємозв’ язки з вченими США, що дозволяє проводити перспективні спільні наукові дослідження.

Висновки. Результати аналізу системи підготовки спеціалістів у медичних ВНЗ Польщі дозволяють зробити висновок, що нині система освіти в Польщі 
функціонує за загальноєвропейською схемою, відповідає міжнародним нормам, що дозволяє лікарям із дипломом польського ВНЗ бути конкурентоздатними й затребуваними як у себе в державі, так і в роз-

\section{Література}

1. Высшее образование в Польше // Сборник Министерства национального образования и спорта Республики Польша. - Варшава, 2005. - 24 с.

2. Вища освіта України і Болонський процес : навчальний посібник / М. Ф. Степко, Я. Я. Болюбаш, В. Д. Шинкарук, винених європейських країнах. Болонська система навчання в Україні може стати запорукою для інтеграції в європейську систему освіти й високої якості підготовки майбутніх вітчизняних спеціалістів.

В. В. Грубінко, І. І. Бабин; за ред. В. Г. Кременя. - Тернопіль : Навчальна книга-Богдан, 2004. - 384 с.

3. POLISH KNOW HOW FOUNDATION // Warecka 4/6, 00-040 Warsaw, POLAND

4. http://www.slam.katowice.pl 